\title{
ON THE BIOLOGY OF CALANUS FINMARCHICUS
}

\section{SEASONAL CHANGES IN OXYGEN CONSUMPTION}

\author{
By S. M. Marshall, D.Sc., and A. P. OrR, D.Sc. \\ Marine Station, Millport
}

(Text-figs. I-5)

The oxygen consumption of Calanus has been studied by various workers. They give figures which, although not precisely the same, are of the same order of size. From these figures can be calculated the food requirements and these may be expressed as a percentage of its weight per day or as the volume of sea water of known richness which it must filter each day. However, a copepod does not feed continuously; when carrying out diurnal vertical migration it feeds chiefly during the hours when it is in the surface layers (Gauld, 1953). Again, the overwintering Stage V Calanus do not migrate vertically (Nicholls, I933), but stay in deep water and at this time phytoplankton is very scarce. Altogether then, the volume of $72 \mathrm{ml}$., calculated as necessary for a Calanus to filter daily when the sea is moderately rich in phytoplankton (Fuller \& Clarke, I936), must be an underestimate for long periods of the year.

Many experiments have been made to find the volume which a Calanus actually does filter daily, with very varying results, from the I ml. of Fuller (I937) to the $250 \mathrm{ml}$. of Harvey (I937). From the decrease of diatom numbers between cruises in the North Sea, Cushing (1955) has calculated that a Calanus may filter as much as $1500 \mathrm{ml}$. daily.

Recently, using cultures labelled with radioactive phosphorus, we concluded (Marshall \& Orr, I955) that the volume is often below $80 \mathrm{ml}$. daily. Confronted with this gap between food required and food available, it seemed desirable to re-investigate oxygen consumption.

\section{METHODS}

In the earlier work two methods were used for the measurement of respiration. In the first (Marshall, Nicholls \& Orr, I935; Clarke \& Bonnet, I939) the Calanus were kept at constant temperature in dark bottles with $\mathrm{I}-4 \mathrm{ml}$. of water to each copepod, and the oxygen consumed over a period of about $4 \mathrm{~h}$ measured by the Winkler method. In the second (Clarke \& Bonnet, I939; Raymont \& Gauld, I95I) respiration was measured with a constant pressure manometer using Calanus in concentrations the same as, or higher than, in the first method. These high concentrations were necessary to obtain a suitable 
reduction in oxygen in a time short enough for bacterial metabolism to be negligible.

The concentration in these experiments was high and the effect of crowding was tested by comparing the oxygen consumption of the same catch of ripe female Calanus in two parallel experiments, one using sixty Calanus in bottles of $60-70 \mathrm{ml}$. capacity for $4 \mathrm{~h}$ at $10^{\circ} \mathrm{C}$ and the other, single Calanus in bottles of about $30-40 \mathrm{ml}$. at $10^{\circ} \mathrm{C}$. In the first (four bottles) the oxygen used, expressed as $\mu 1$. /Calanus $/ \mathrm{h}$, ranged from 0.336 to 0.392 and averaged 0.367 ; in the second (nine bottles) the range was from 0.220 to $0.348 \mu \mathrm{l}$./Calanus $/ \mathrm{h}$ and the average 0.304 . The crowding may therefore have affected the oxygen consumption slightly. On the other hand, when the concentration was changed from Io in a $35 \mathrm{ml}$. bottle to 3 , there was only a small difference in respiration. Another experiment comparing 100 Calanus in $160 \mathrm{ml}$. bottles with single Calanus in $60 \mathrm{ml}$. bottles for a longer time gave similar results.

By the use of antibiotics the bacterial population can be controlled so that an experiment may be allowed to last a much longer time. According to Oppenheimer (1955) penicillin is one of the most effective in sea water, but unfortunately it reacts with the iodine liberated in the Winkler method for oxygen determination and so it could not be used. We therefore used a mixture of equal parts of streptomycin and chloromycetin which were both found by Oppenheimer to be very effective in concentrations of $50 \mathrm{mg} / \mathrm{l}$. With these, only slight changes in the oxygen content of a control sample of sea water occurred over a period of up to a fortnight. At the end of this time there was usually a sudden breakdown of the antibiotic effect and a correspondingly sharp fall in the oxygen content of control bottles. In some instances moulds also developed. Antibiotics are best added to the filtered sea water at least Io $\mathrm{h}$ before an experiment since the oxygen content may fall appreciably during this period, thereafter remaining constant at the lower level.

The method eventually adopted was to keep three Calanus, which had been picked out from townettings taken the previous day, for 2 days in a bottle of $30-40 \mathrm{ml}$. capacity at $10^{\circ} \mathrm{C}$, which is within the annual temperature range in the sea for this latitude. The water used was taken directly from the sea and passed through a membrane filter of about I $\mu$ average pore diameter and the antibiotics added ( $50 \mathrm{mg} / 1$. of each). If sufficient numbers were available, ten experimental bottles were used for each stage and four or five controls.

Respiration was measured on Stage V, ripe and unripe females of both the finmarchicus and the helgolandicus forms, males, and young stages as each was available. In the early experiments Stage $\mathrm{V}$ and female Calanus were not distinguished as finmarchicus or helgolandicus but these forms were later (from October, 1956) tested separately and, from July 1956, ripe females were separated from immature, the intermediate stages of maturity being discarded. From July 1956 also the carapace length of all specimens used was measured. These measurements were made after the copepods had been exposed to alkali 
and acid in the oxygen determination and, although comparable among themselves, may differ slightly from those of formalin-fixed specimens.

It was not possible to follow any stage throughout a complete year. From the end of October to the end of February ripe finmarchicus females were absent whereas during the summer months immature females were very scarce. The finmarchicus form is predominant throughout the spring and summer, the helgolandicus form during the autumn. Stage V copepodites of both forms were absent during March.

Smaller bottles and larger numbers of individuals were used for the younger stages. For nauplii and even for Copepodites I and II the bottles had to be very small (2-IO ml.) to get a measurable reduction in the oxygen and this was determined by the method of Fox \& Wingfield (1938). On the suggestion of Dr M. R. Droop a slight improvement was made in the method. After the reagents are sucked up into the barrel of the pipette, a small bead of mercury is introduced by a half turn of the milled head. This acts as a 'stirrer' when the pipette is shaken and gives a more uniform and finely divided precipitate. Duplicate samples then give much closer results.

The early nauplii can be readily obtained from eggs allowed to hatch in the laboratory; they develop up to Nauplius III without requiring food (Marshall \& Orr, I956). The later nauplius stages, as well as the earlier copepodites, were picked out from the plankton but only small numbers were obtained.

One difficulty, particularly with the small individuals, was that if one animal only was used, the oxygen reduction was little beyond experimental error, whereas if several were used some were likely to moult and so give less reliable results. The figures from those bottles in which a significant proportion had moulted (except with nauplii) or died, were rejected.

Several hundred Nauplius I or II were used at a time but it was difficult to ensure that all those counted were actually put in the experimental bottle; some were always lost with the insertion of the stopper. The count at the end was therefore used for calculation. Since Nauplii I and II usually moult within $24 \mathrm{~h}$, the majority moulted during the course of an experiment and the first point on the curve (Fig. 2) therefore represents Nauplii I and II.

\section{EXPERIMENTAL WORK}

It seemed possible that the metabolism of Calanus might be reduced in winter not only by the lower temperature but also by the decrease in food supply, and the winter be spent in a state of 'hibernation'. To test this, Stage V Calanus captured in winter were kept singly at constant temperature (usually $10^{\circ} \mathrm{C}$ ) in bottles of about $70 \mathrm{ml}$. capacity. The Calanus were first kept in the laboratory overnight to avoid the fall in respiration which occurs during the first $24 \mathrm{~h}$ after capture (Marshall et al. 1935). A large number of bottles was set up and the oxygen consumption measured every 3 or 4 days by removing 
eight or ten bottles and drawing off samples for analysis. The oxygen consumption varied considerably from one individual to another but on the whole it was decidedly lower than the earlier published results. Each of the experiments lasted for a little over 2 weeks but there was no indication that respiration decreased with time. The earlier figure taken for Stage $\mathrm{V}$ at $10^{\circ} \mathrm{C}$ was $0.25 \mu \mathrm{l}$./Calanus $/ \mathrm{h}$, but in these long-term winter experiments the average was 0.14 .

Experiments were continued into the spring months and the respiration then began to rise, reaching a figure of $0.560 \mu \mathrm{l}$./Calanus $/ \mathrm{h}$ for immature females at $10-14.5^{\circ} \mathrm{C}$. At first it was thought that the high value might be caused by bacterial infection. In the following winter further experiments were made by the standard method using antibiotics and were carried on more or less regularly throughout the year. Once again one or two very high results were obtained in the spring and it then became clear that there was a seasonal variation in oxygen consumption.

\section{TABLE 1. FALL IN RESPIRATION WITH TIME}

\begin{tabular}{|c|c|c|c|c|c|}
\hline \multicolumn{3}{|c|}{ I956 } & \multicolumn{3}{|c|}{ I957 } \\
\hline $\begin{array}{l}\text { Total } \\
\text { hours }\end{array}$ & $\begin{array}{c}\mathrm{O}_{2} \mu \mathrm{l} . / C . / \mathrm{h} \\
\text { for total }\end{array}$ & $\begin{array}{l}\text { Calculated } \\
\mu \mathrm{l} . / C . / \mathrm{h} \text { for } \\
\text { period }\end{array}$ & $\begin{array}{l}\text { Total } \\
\text { hours }\end{array}$ & $\begin{array}{l}\mathrm{O}_{2} \mu 1 . / C . / \mathrm{h} \\
\text { for total }\end{array}$ & $\begin{array}{l}\text { Calculated } \\
\mu 1 . / C . / \mathrm{h} \text { for } \\
\text { period }\end{array}$ \\
\hline 69.5 & 0.508 & 0.508 & 47 & 0.591 & 0.591 \\
\hline I $4 \mathrm{I} \cdot 5$ & 0.506 & 0.504 & 96 & 0.493 & 0.399 \\
\hline $2 I_{3}$ & 0.376 & 0.119 & I92 & 0.495 & 0.497 \\
\hline 293 & 0.342 & $0.25 \mathrm{I}$ & 288 & 0.431 & 0.303 \\
\hline $35 \% \cdot 5$ & 0.304 & 0.130 & & & \\
\hline
\end{tabular}

The seasonal changes are shown in Fig. I and Table 2. In I 956 the respiration of females (Fig. I B) was low at the beginning of April. There was then a rapid rise and values remained high until the middle of May. By June they had fallen to near winter values again. During spring and summer females were almost certainly $C$. finmarchicus and mostly ripe. In the following year the spring rise was earlier. It lasted from the beginning of April to the middle of June when there was a rapid fall.

During the spring of 1956 , when respiration was near its peak, twenty-five female Calanus were kept singly in $70 \mathrm{ml}$. bottles and their oxygen consumption measured at 3-day intervals, to show if the high figure would be maintained. Control samples of sea water were analysed at the same time. Consumption remained high for the first 6 days and then fell. If allowance is made for the initial period of high respiration, it can be shown (Table $I$ ) that the fall is considerable and that the respiration reached winter values by the end of the experiment. This was repeated with similar but less striking results in 1957 .

The results for Stage V, immature female C. finmarchicus and males from October 1956 to late 1957 are shown in Fig. IC. For males most values are 
TABLE 2. OXYGEN CONSUMPTION OF ADULT AND STAGE V CALANUS

At $10^{\circ} \mathrm{C}$ in experiments lasting $48 \mathrm{~h}$. The measurement in the second column represents length.

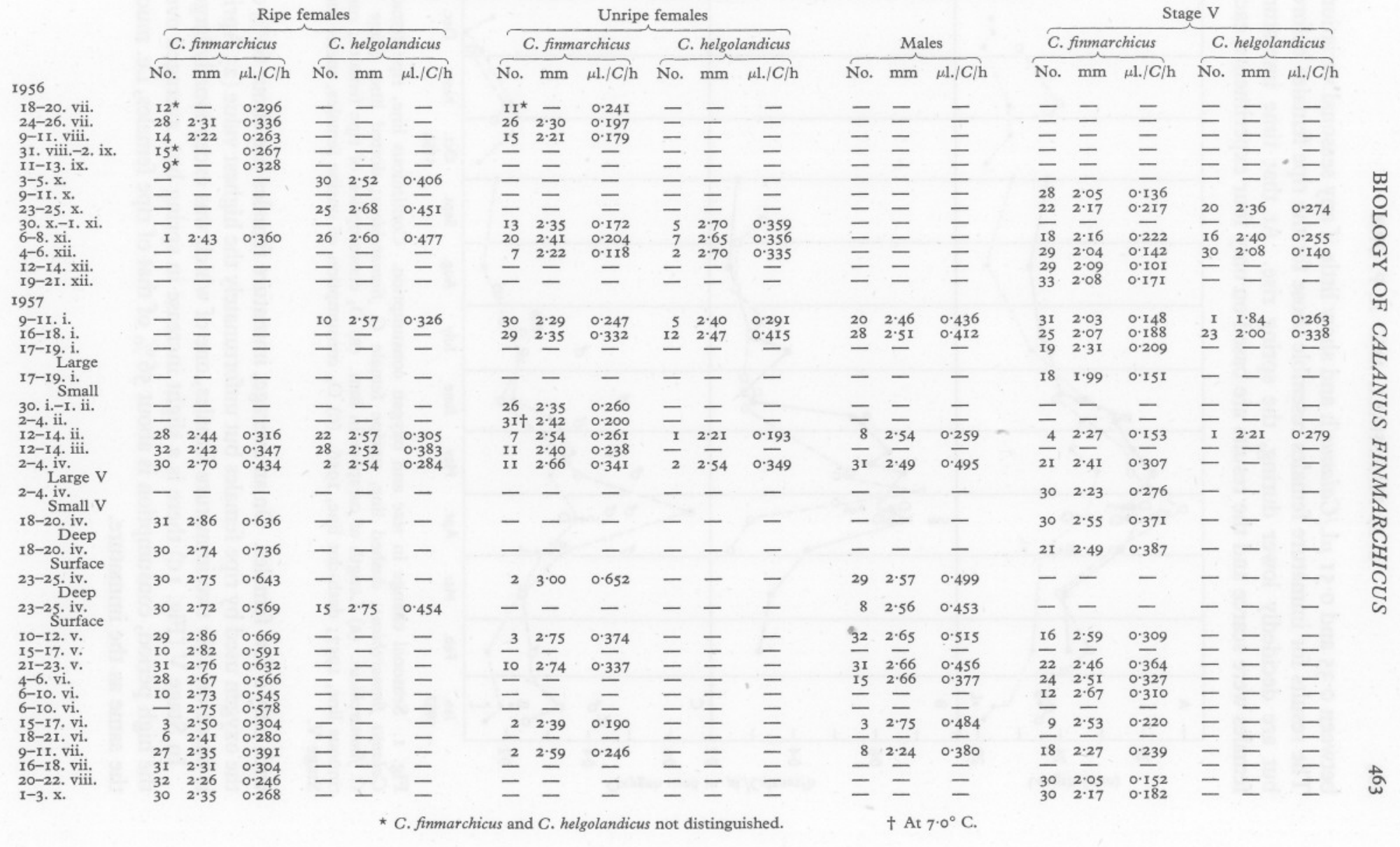


between 0.35 and $0.5 \mathrm{I} \mu \mathrm{l}$./Calanus/h and show little if any seasonal variation. The results for immature females resemble those for the ripe females before, but are decidedly lower during, the spring rise. At that time immature females were scarce and the results are based on only four experiments, each

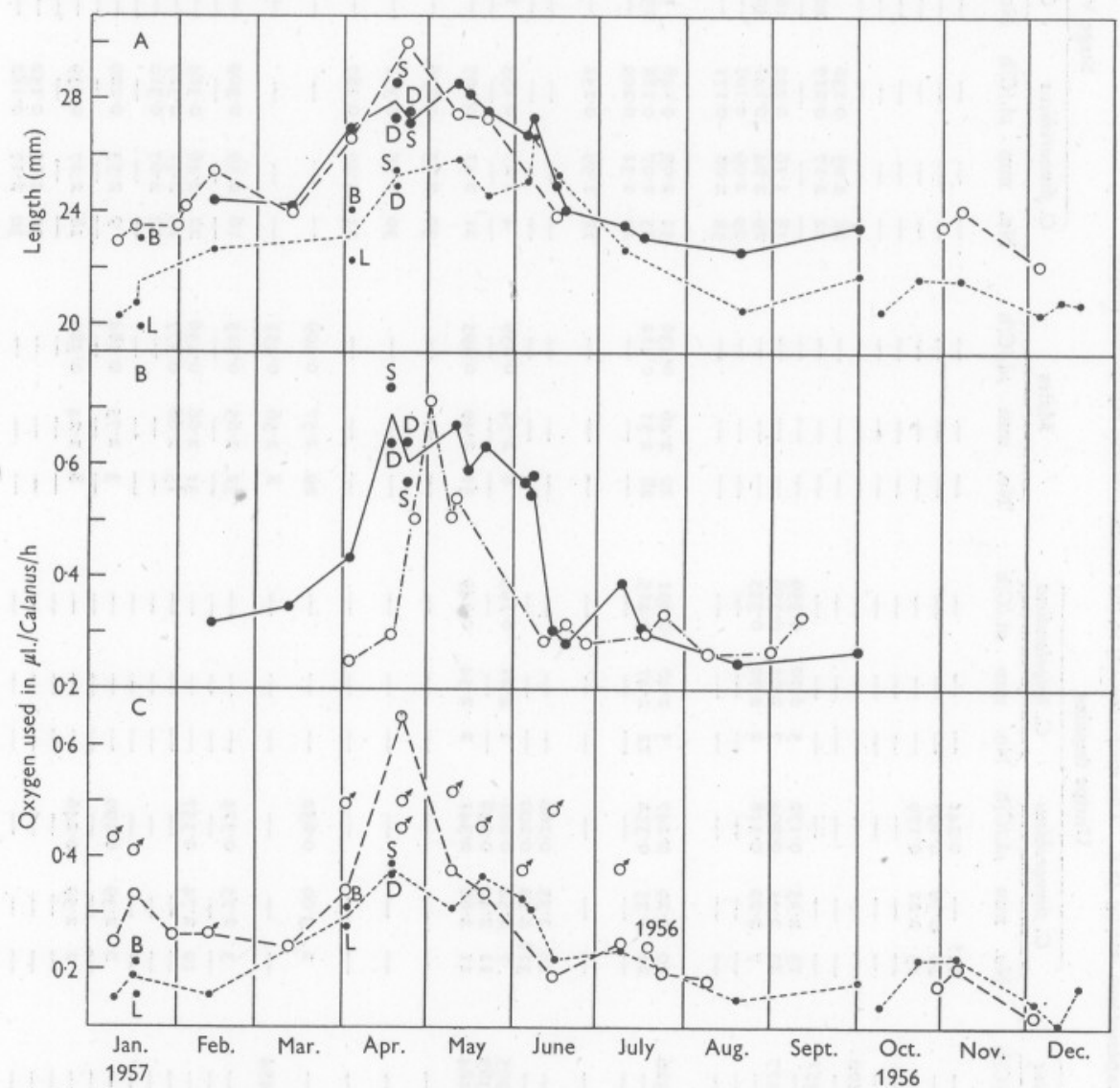

Fig. I. Seasonal change in size and oxygen consumption. Continuous line, ripe female Calanus finmarchicus; dashed line, unripe female $C$. finmarchicus; dotted line, Stage V C. finmarchicus. (A) Length of carapace in $\mathrm{mm}$. (B) $\mathrm{O}_{2}$ consumption of ripe females; continuous line, 1957; dash-dot line, 1956 . (c) $\mathrm{O}_{2}$ consumption of unripe females, males and Stage V.

with only a few females. On an average, immature females use about $60 \%$ of the oxygen used by ripe females but unfortunately the highest value ( 23 April) is based on only two immature females, one of which was exceptionally large.

In Stage V (Fig. IC) there is a slight increase in spring but, averaged over the high period, consumption is about $56 \%$ of that of ripe females, i.e. much the same as the immature. 
When the results from all the experiments done with Dr A. G. Nicholls in 1930-32 were re-examined, it was found that as has already been suggested (Riley, Stommel \& Bumpus, 1949; Gauld \& Raymont, 1953), in them also there was a considerable seasonal variation. When those done at $10^{\circ} \mathrm{C}$ were arranged according to date, there was seen to be an irregular rise in the oxygen consumed from February to the end of April and several high values in the beginning and middle of May. The lowest values, those in February and March, were rather higher than those in 1956-57 and this might have been because of the method used.

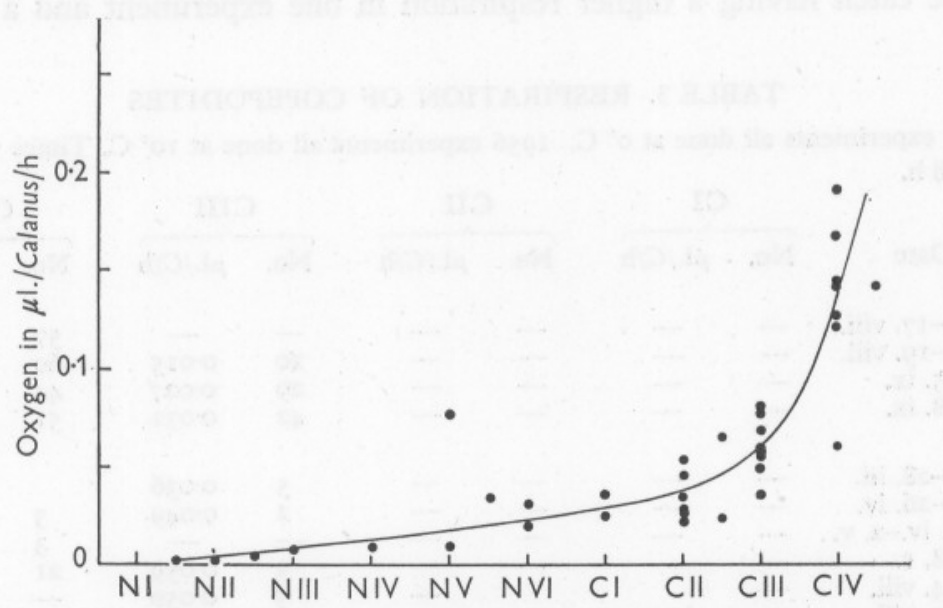

Fig. 2. Oxygen consumption of the early stages of Calanus. NI-NVI, nauplius stages; CI-CIV copepodite stages.

In the Clyde Sea Area the helgolandicus form is slightly larger than the finmarchicus and, as might be expected, the figures for respiration are slightly higher too. In spring 1957, however, when the two forms were almost the same size, the respiration of the ripe female finmarchicus was higher than that of the helgolandicus form. The helgolandicus form usually disappears before the first generation has developed and so there is no way of telling if they have a period of high respiration corresponding to that in finmarchicus (see, however, p. 467).

In both 1956 and 1957 Calanus were scarce during the summer and few early stages were obtainable. Their oxygen consumption was therefore measured mainly in April, May, and September to November. The experimental error of the determinations is relatively large and no clear seasonal cycle can be made out. The results are shown in Fig. 2 and Tables 3 and 4, and on the whole give a smooth curve ranging from $0.002 \mu 1$./Calanus $/ \mathrm{h}$ for Nauplii I-II up to $0.15 \mu \mathrm{l}$./Calanus/h for Copepodite IV. There is no abrupt rise with the change from nauplius to copepodite. 
There are several factors which might cause an increase in respiration during the spring months, and among these are increased light, increased food, increased temperature and increased size.

Light is a factor which has been found to have a marked effect in raising respiration in Calanus. It might therefore be expected that the first generation, which is often surface living, should have a higher respiration rate than other generations. On two occasions (see $D$ and $S$ on Fig. I B, c) samples of firstgeneration Calanus were taken from deep and surface water at the same time and their oxygen consumption compared. The results were contradictory, the surface catch having a higher respiration in one experiment and a slightly

\section{TABLE 3. RESPIRATION OF COPEPODITES}

I955 experiments all done at $0^{\circ} \mathrm{C}$. 1956 experiments all done at $10^{\circ} \mathrm{C}$. Times vary from I9 to $48 \mathrm{~h}$.

\begin{tabular}{|c|c|c|c|c|c|c|c|c|}
\hline & & $\mathrm{CI}$ & & II & & III & & IV \\
\hline Date & No. & $\mu \mathrm{l} . / C / \mathrm{h}$ & No. & $\mu \mathrm{l} . / C / \mathrm{h}$ & No. & $\mu 1 . / C / \mathrm{h}$ & No. & $\mu \mathrm{l} . / C / \mathrm{h}$ \\
\hline I955 & & & & & & & & \\
\hline I6-I7. viii. & - & - & - & 一 & - & - & 57 & 0.038 \\
\hline I7-r9. viii. & - & 一 & - & 一 & 20 & 0.015 & 60 & 0.037 \\
\hline $3-5 . \mathrm{ix}$ & - & - & - & 一 & 29 & 0.027 & 44 & 0.065 \\
\hline 6-8. ix. & - & - & - & - & 42 & 0.032 & $5 I$ & 0.058 \\
\hline I956 & & & & & & & & \\
\hline 26-28. iii. & - & - & - & - & 5 & 0.036 & & \\
\hline $24-26$. iv. & - & - & - & - & 2 & 0.049 & 3 & $0.14 I^{\star}$ \\
\hline 3o. iv. -2 . v. & 一 & - & - & 一 & - & - & 3 & 0.167 \\
\hline $7-8 . v$ & - & - & - & 一 & 3 & 0.059 & 21 & 0.145 \\
\hline 3-4. viii. & - & & & - & 5 & 0.050 & $\bar{z}$ & - \\
\hline 6-7. viii. & 3 & O.0II & 29 & 0.029 & 34 & 0.070 & 19 & 0.142 \\
\hline 8-ro. viii. & - & - & I & 0.027 & - & - & - & - \\
\hline I6-I8. viii. & I & 0.036 & I & 0.052 & 一 & - & - & - \\
\hline 20-22. viii. & - & - & I & 0.023 & - & - & 一 & - \\
\hline $3-5 \cdot x$ & 一 & - & - & - & 6 & 0.057 & - & $\overline{0}$ \\
\hline 9-II. X. & - & - & 一 & - & - & - & 7 & 0.060 \\
\hline $22-23 . x$. & - & 一 & 3 & 0.054 & 7 & 0.081 & Io & 0.127 \\
\hline 29-30. x. & - & 一 & I & 0.046 & - & - & - & - \\
\hline 5-6. xi. & - & - & - & - & 8 & 0.078 & I3 & $0 \cdot 12 I$ \\
\hline
\end{tabular}

TABLE 4. RESPIRATION OF CALANUS NAUPLII

Nauplii I-II and II-III Nauplius III Nauplius IV Nauplius V Nauplius VI

Date $\overbrace{\text { No. } \mu \mathrm{l} . / C / \mathrm{h}} \overbrace{\text { No. } \mu \mathrm{l} . / C / \mathrm{h}} \overbrace{\text { No. } \mu \mathrm{l} . / C / \mathrm{h}} \overbrace{\text { No. } \mu \mathrm{l} . / C / \mathrm{h}} \overbrace{\text { No. } \mu \mathrm{l} . / C / \mathrm{h}} \overbrace{\text { No. } \mu \mathrm{l} . / C / \mathrm{h}}$ I956

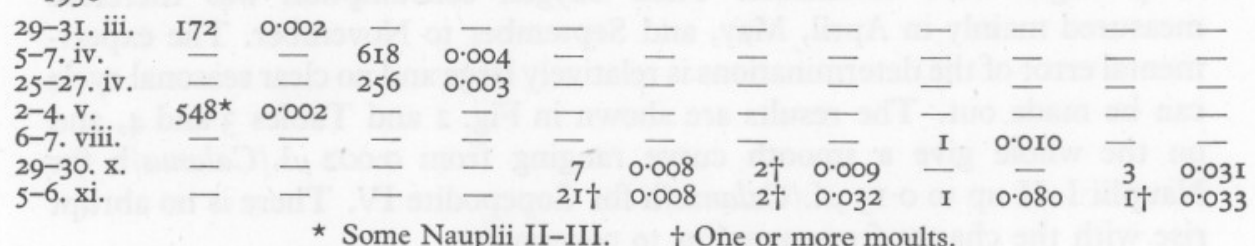


lower one in the other. Bainbridge (1952), from observations while diving, has described a continuous interchange between the Calanus at the surface and those deeper down so that a clear difference between them should not be expected. This, however, would not exclude the possibility that it was the greater exposure to light of the surface-living generation which caused the increased respiration.

In the English Channel it is not the Calanus of the first but those of a later generation in July or August which are found at the surface (Russell, 1928), although the form is helgolandicus. The respiration of those from the surface and from deeper water was measured in August 1957 at Plymouth, and was found to be no higher than that of the finmarchicus form in the Clyde Sea Area at the same time although it was the same size. We may therefore conclude that the higher light intensity received by those living near the surface is not responsible for the increase in respiration.

The increase in respiration in the spring of 1957 began at the same time as the diatom maximum, but this was over by 22 April, whereas respiration remained high until the beginning of June. It then dropped suddenly and remained low in spite of a second but smaller diatom increase in the first part of June.

Attempts to starve ripe female Calanus in the laboratory over a long period were not successful. A few specimens died and eggs were laid providing some food for the rest. A comparison of the respiration of these with that of fed Calanus showed little difference. Tests were also made with the filtrate from diatom culture to find out whether it increased the respiration of a variety of small copepods (Centropages, Temora, Acartia); there was no effect.

Two thyroid derivatives which might be expected to have an effect on respiration were tested at the suggestion of Dr J. M. Dodd, St Andrews. Sodium L-thyroxine and triiodothyronine, each in a dilution of $10^{-6}$, were used, again with negative results.

The increase of temperature in spring is much too slight to be the sole cause of the rise in respiration (Marshall, Nicholls \& Orr, I935; Clarke \& Bonnet, I939) and in any case it goes on rising when the respiration falls in June and July.

In 1930-33 a series of experiments was made to find the effect of temperature. Each series was done with the same set of Calanus, which involved subjecting the same individuals to a series of rising temperatures up to $20^{\circ} \mathrm{C}$ and repeating the lower temperatures to see whether they had been damaged. Almost invariably the second test at the same temperature (usually $10^{\circ} \mathrm{C}$ ) showed a lower result than the first indicating that the Calanus had suffered somewhat. The result chosen for publication was that in which this fall was least marked. All the experiments were done in February or August and, together with one done in August 1957 by the modified method, are shown in Fig. 3. It will be seen that there is a considerable range of variation and 
a tendency for the oxygen consumption to be higher at the same temperature in summer than in winter. The February females would be mainly unripe and the August ripe, which would account for the difference.

Another possible cause of the variation in respiration might be the variation in size. On two occasions Stage V Calanus were separated roughly by eye into a large and a small group (see $B$ and $L$ in Fig. I A, C) and the respiration measured separately. There was some overlap both in lengths and in the oxygen values in the two sets of bottles but the oxygen consumption of the

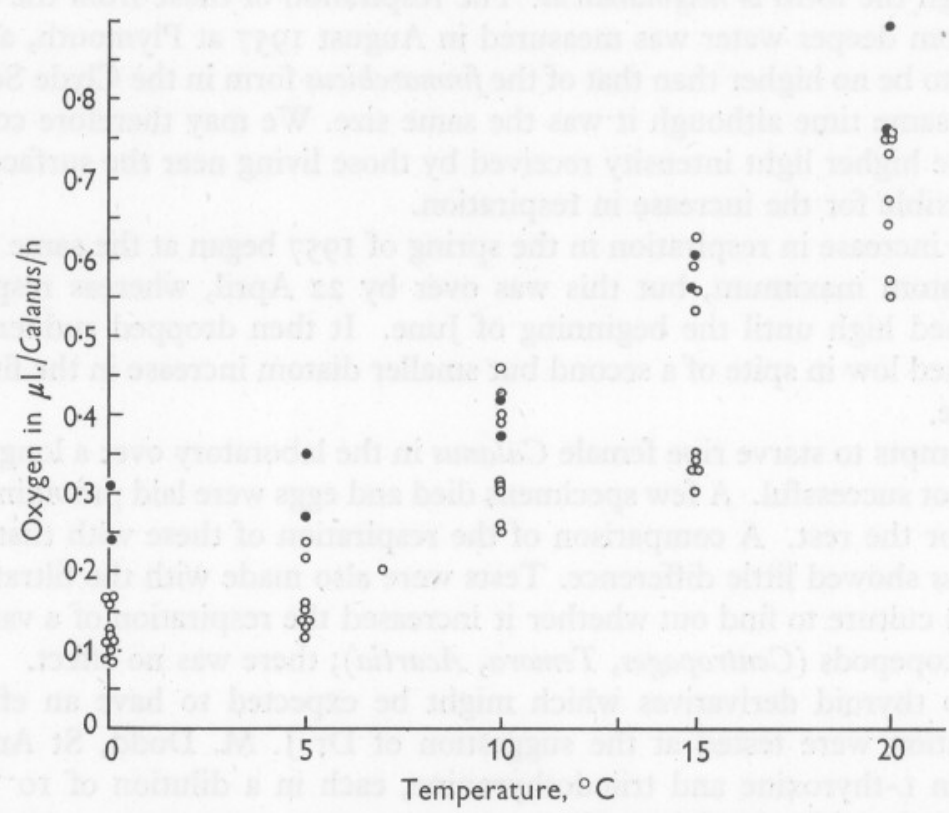

Fig. 3. Effect of temperature on the oxygen consumption of female Calanus. Open circles, February experiments; closed circles, August experiments.

large specimens was not so much greater as would be expected if size were the only cause of the respiration differences. In January, for instance, the average lengths were $2.3 \mathrm{I}$ and $\mathrm{I} .99 \mathrm{~mm}$ and the oxygen consumption $0.2 \mathrm{I}$ and $0.15 \mu \mathrm{l}$./Calanus/h.

The largest Calanus are those of the first generation of the year, appearing as adults about the beginning of April. The overwintering stock gradually dies off and at the end of April and in May only large first-generation Calanus are found. After this the length decreases gradually and irregularly until the winter when it is at its minimum. It is therefore the large females of the first generation which have the exceptionally high oxygen consumption. It is noteworthy, however, that the unripe females of the first generation, although comparable in size with the ripe, have a much lower respiration (Fig. I A, C). 
Gauld \& Raymont (I953) found differences in respiration between different generations of Centropages which did not depend on length.

If the length of the females is plotted against respiration (as can be done for some of the 1956 and all of the 1957 experiments), almost all the points for ripe Calanus lie well above those for unripe. The calculated lines (on a logarithmic scale) are shown in Fig. 4. The points for the ripe females of the first generation appear to be slightly above the upper line, which suggests that it is not length alone which accounts for their high respiration. This difference between the generations is not seen in unripe females.

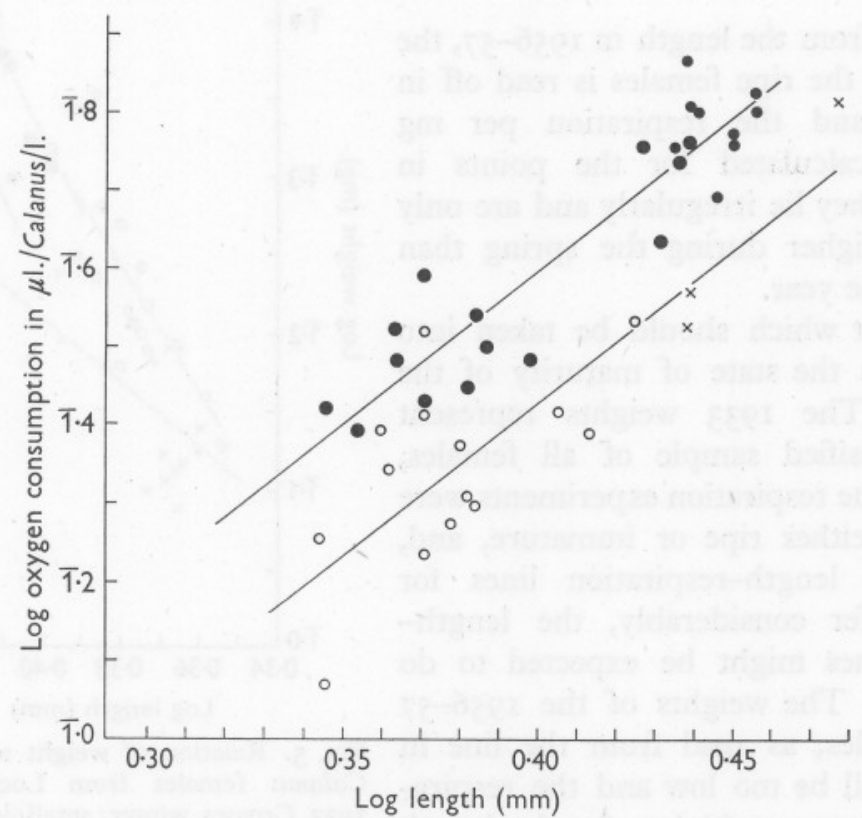

Fig. 4. Relation of length to oxygen consumption in C. finmarchicus females, 1956-57. Small closed circles, first-generation ripe females; large closed circles, all other ripe females; crosses, first-generation unripe females; open circles, all other unripe females. Lines calculated by the method of least squares.

The line for Stage V Calanus is not shown but lies between those for the ripe and the unripe. Not enough data are available for either males or for the helgolandicus form, although the relationship is not widely different.

A more useful measure than size might be the oxygen consumed per mg of Calanus. Unfortunately it is not possible to plot the respiration of the experimental animals against their own weight, but a series of weekly measurements of length and dry weight of male, female and Stage V Calanus is available from Loch Striven in I933 (Marshall, Nicholls \& Orr, 1934) and these may fairly be used. 
When weight is plotted against length for the 1933 Calanus females, they fall into several distinct groups (Fig. 5). The points for the winter females are scattered and lie mainly on the lower part of the graph. These Calanus are the survivors of the late summer broods and the lower values show their loss of weight during the winter. Those of the first generation are, for a given length, lighter than those of the second and third. Thus although they have the maximum weight for the year, it is only because of their greater length.

When from the length in $1956-57$, the weight of the ripe females is read off in Fig. 5, and the respiration per $\mathrm{mg}$ Calanus calculated for the points in Fig. I B, they lie irregularly and are only slightly higher during the spring than later in the year.

A factor which should be taken into account is the state of maturity of the females. The 1933 weights represent an unclassified sample of all females, whereas the respiration experiments were done on either ripe or immature, and, since the length-respiration lines for these differ considerably, the lengthweight lines might be expected to do the same. The weights of the 1956-57 ripe females, as read from the line in Fig. 5, will be too low and the respiration thus appears higher for the length than one would expect. The converse holds for the unripe females. The exceptionally high oxygen consumption

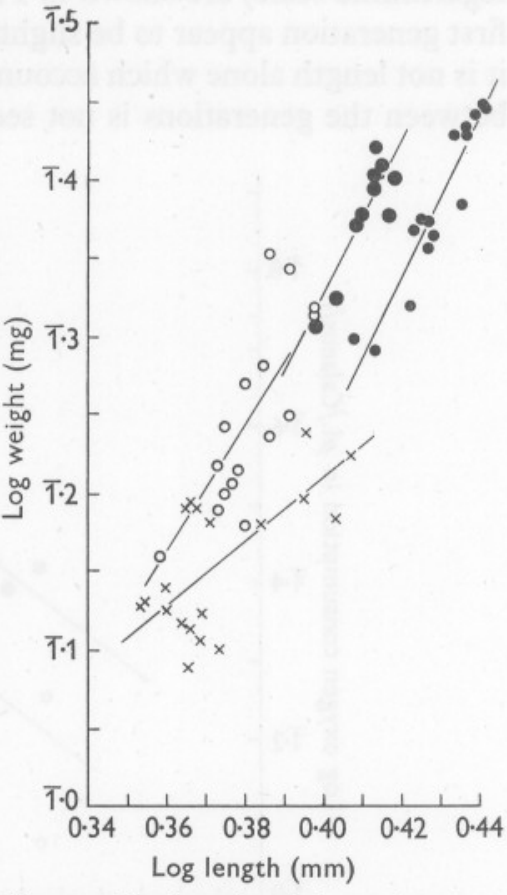

Fig. 5. Relation of weight to length in Calanus females from Loch Striven, 1933. Crosses, winter; small closed circles, first generation; large closed circles, second generation; open circles, third and later generations. Lines calculated by the method of least squares. of the ripe females of the first generation may be partly caused by the extra weight of the eggs.

If the relationship of length to dry weight for the whole populations of males, females and Stage V Calanus in 1933 is calculated, the lines for males and females are not significantly different. Stage V is, however, much heavier per unit length and its line is significantly different from the others. In spite of this the respiration of the Stage $\mathrm{V}$ is lower.

The figures for Stage V can be analysed into broods as for the females in Fig. 5. They then fall into the same groups; a small and light overwintering generation, a large but relatively light first generation and a succession of 
smaller but relatively heavier broods in summer. The overwintering Stage V show a fall in weight from autumn to January. If the respiration per mg dry weight is calculated from the 1933 figures, the seasonal changes are, as for females, very irregular but show a tendency to be lower for the first than for the overwintering generation. This is probably because of the much higher fat content of the former.

We should like to thank the Trustees of the Browne Fund for a grant which enabled us to work on Calanus in the English Channel. We are also grateful to the Director and Staff of the Plymouth Laboratory for their hospitality. Mr T. B. Bagenal gave helpful advice on statistical problems and Dr J. M. Dodd supplied us with thyroxine compounds; to them and to the Master and crew of the research vessels 'Calanus' and 'Mizpah' who kept us supplied with tow-nettings we should like to express our thanks.

\section{SUMMARY}

The seasonal changes in the respiration of Calanus are considerable and are, on the whole, related to size and therefore to weight. Length alone is not enough to account for the differences since ripe females, although the same length as unripe, have a markedly higher respiration. In addition, by taking samples of large and of small Calanus of a single stage, it was shown that the difference in respiration was small. Neither is weight by itself enough to account for the difference between groups. Stage V Calanus are, for a given length, heavier even than ripe females and yet their oxygen utilization is low. In this instance, however, an important part of the weight consists of fat which is a food reserve and not actively metabolizing. The difference of weight between ripe and unripe females is not known, but ripe females must be heavier and this will account for their higher oxygen consumption.

Although the oxygen and therefore the food required during the spring months is high, at that time the phytoplankton is at its maximum and is probably sufficient to fulfil all needs. Egg-laying depends on the food supply and it is then that Calanus starts breeding. In winter, on the other hand, the Calanus is present as Stage $\mathrm{V}$ and oxygen consumption is little more than half what earlier figures suggested. No 'hibernation' seems to take place but the population is living in an economical way for Stage $\mathrm{V}$ use little oxygen, live in deep water and do not undertake diurnal vertical migration.

At $10^{\circ} \mathrm{C}$ ripe female Calanus will require daily from $3 \cdot 9-7 \cdot 2 \%$ of their body weight as dry matter in summer and from $2 \cdot 8-6 \cdot 7 \%$ in winter. Stage V will require $2 \cdot 3-3 \cdot I \%$ in summer and $\mathrm{I} \cdot 4-3.3 \%$ in winter. The higher values are for carbohydrate and the lower for fat.

It is difficult to believe that Calanus in winter will be able to find enough food by filtration alone. The fact that in the winter months it depends more on predation may account for its survival. 


\section{REFERENCES}

BAINBRIDGE, R., I952. Underwater observations on the swimming of marine zooplankton. F. mar. biol. Ass. U.K., Vol. 31, pp. 107-12.

Clarke, G. L. \& Bonnet, D. D., 1939. The influence of temperature on the survival, growth and respiration of Calanus finmarchicus. Biol. Bull., Woods Hole, Vol. 76, pp. $37 \mathrm{I}-83$.

Cushing, D. H., 1955. Production and a pelagic fishery. Fish. Invest. Lond., Ser. 2, Vol. I8, No. 7, $104 \mathrm{pp}$.

Fox, H. M. \& WINGFIELD, C. A., I938. A portable apparatus for the determination of oxygen dissolved in a small volume of water. F. exp. Biol., Vol. 15, pp. 437-45.

FULLER, J. L., I937. Feeding rates of Calanus finmarchicus in relation to environmental conditions. Biol. Bull., Woods Hole, Vol. 72, pp. 233-46.

Fuller, J. L. \& Clarke, G. L., 1936. Further experiments on the feeding of Calanus finmarchicus. Biol. Bull., Woods Hole, Vol. 70, pp. 308-20.

GAULD, D. T., I953. Diurnal variations in the grazing of planktonic copepods. F. mar. biol. Ass. U.K., Vol. 3I, pp. 46I-74.

GAULD, D. T. \& RaYMont, J. E. G., 1953. The respiration of some planktonic copepods. II. The effect of temperature. F. mar. biol. Ass. U.K., Vol. 3I, pp. $447-60$.

Harvey, H. W., 1937. Note on selective feeding by Calanus. F. mar. biol. Ass. U.K., Vol. 22, pp. 97-I00.

Marshall, S. M., Nicholls, A. G. \& OrR, A. P., I934. On the biology of Calanus finmarchicus. V. Seasonal distribution, size, weight and chemical composition in Loch Striven in 1933 and their relation to the phytoplankton. F. mar. biol. Ass. U.K., Vol. I9, pp. 793-827.

- I935. On the biology of Calanus finmarchicus. VI. Oxygen consumption in relation to environmental conditions. f. mar. biol. Ass. U.K., Vol. 20, pp. $\mathrm{I}-28$.

Marshall, S. M. \& ORR, A. P., I955. On the biology of Calanus finmarchicus. VIII. Food uptake, assimilation and excretion in adult and Stage V Calanus. f. mar. biol. Ass. U.K., Vol. 34, pp. 495-529.

_ 1956. On the biology of Calanus finmarchicus. IX. Feeding and digestion in the young stages. F. mar. biol. Ass. U.K., Vol. 35, pp. 587-603.

Nicholls, A. G., 1933. On the biology of Calanus finmarchicus. III. Vertical distribution and diurnal migration in the Clyde sea area during 1932. F. mar. biol. Ass. U.K., Vol. 19, pp. 139-64.

OPPENHEIMER, C. H., I955. The effect of marine bacteria on the development and hatching of pelagic fish eggs and the control of such bacteria by antibiotics. Copeia, 1955, pp. 43-9.

Raymont, J. E. G. \& GAULD, D. T., I95I. The respiration of some planktonic copepods. F. mar. biol. Ass. U.K., Vol. 29, pp. 68I-93.

Riley, G. A., Stommel, H. \& Bumpus, D. F., 1949. Quantitative ecology of the plankton of the western North Atlantic. Bull. Bing. oceanogr. Coll., Vol. I2, No. 3, $169 \mathrm{pp}$.

RUSSELL, F. S., 1928. The vertical distribution of marine macroplankton. VII. Observations on the behaviour of Calanus finmarchicus. F. mar. biol. Ass. U.K., Vol. I5, pp. 429-54. 